\title{
Site U1311
}

\author{
Expedition 304/305 Scientists ${ }^{2}$
}

\section{Chapter contents}

Principal results . . . . . . . . . . . 1

Operations summary. ...........

Figure...................

Table $\ldots \ldots \ldots \ldots \ldots \ldots \ldots \ldots \ldots \ldots$

${ }^{1}$ Expedition 304/305 Scientists, 2006. Site U1311. In Blackman, D.K., Ildefonse, B., John, B.E., Ohara, Y., Miller, D.J., MacLeod, C.J., and the Expedition 304/305 Scientists. Proc. IODP, 304/305: College Station TX (Integrated Ocean Drilling Program Management International, Inc.). doi:10.2204/ iodp.proc.304305.105.2006

'Expedition 304/305 Scientists' addresses.

\section{Principal results}

Site U1311 is located on a small knoll near the break in slope where the corrugated dome meets the adjacent volcanic hanging wall block (see Fig. F2 in the "Site U1309" chapter and Fig. F2 in the "Expedition 304/305 summary" chapter). The hole was cited based on the possibility that the knoll represents a thin klippe of basalt above the detachment surface. Recovery of fresh glassy vesicular basalt in Hole U1311A does not provide a definitive test of this hypothesis. The eruptive basalt could have come from the inferred hanging wall, as hypothesized, or it could have been erupted onto or against the slope of the easternmost surface of the dome at any time after exposure at the seafloor.

Hole U1311A $\left(30^{\circ} 10.61^{\prime} \mathrm{N}, 42^{\circ} 04.19^{\prime} \mathrm{W} ; 2552\right.$ meters below sea level) is located on the southern slope of the knoll. A $60 \mathrm{~m} \times 60 \mathrm{~m}$ survey with the vibration-isolated television camera documented a $\sim 3600 \mathrm{~m}^{2}$ area of mud- and rubble-covered seafloor, with a moderate slope to the south-southeast. Along the northeastern corner of the survey area, a moderately to steeply southeast dipping, $>20$ m high scarp oriented east-northeast $\left(\sim 75^{\circ}\right)$ crops out and is characterized by rounded pillow structures.

One attempt to drill at this site penetrated 12 meters below seafloor, including $3.5 \mathrm{~m}$ of unconsolidated mud. Recovery from the hole produced $1.5 \mathrm{~m}(13 \%)$ of fresh, vesicular, moderately plagioclase-olivine phyric basalt pillows, with sparse glass preserved. Almost all pieces are angular and have broken along fracture surfaces within pillows-few, if any, were cut by the drill. The fracture surfaces are discolored dark brown and minimally altered. These observations suggest that the core is derived from in situ pillows. Some piece interiors include multiple gray Liesegang bands, indicating pervasive minor or incipient alteration. Vesicles close to fracture surfaces are internally discolored brown but not filled.

The basalt is dark gray to black in color and characterized by abundant (5\%-10\%) seriate plagioclase that locally occurs in radiating clumps. Sparse euhedral plagioclase phenocrysts range upward in size to $\sim 2 \mathrm{~mm}$. In thin sections taken from pillow interiors, the basalt appears fresh, with minimal darkening of the matrix and local orange to green smectites either in vesicles or in the vicinity of olivine (see Fig. F3 in the "Expedition 304/305 summary" chapter). Randomly oriented acicular to prismatic plagioclase, ranging in size from $<0.1$ to $0.5 \mathrm{~mm}$, makes up $40 \%$ of the sample. Many of the plagioclase crystals have a hollow or 
swallowtail quench morphology. Olivine microphenocrysts $(\sim 5 \%)$ appear either in subophitic crystal clots with plagioclase or as euhedral microphenocrysts ranging in size from 0.1 to $0.3 \mathrm{~mm}$ and in shape from larger prisms to smaller diamonds and more complex quenched forms. The remainder of the rock is the devitrified glass matrix, dominated by plumose quenched clinopyroxene with anhedral interstitial plagioclase. Oxide intervals are abundant, up to $2 \%$, in the matrix and are mostly present as complex quench morphologies, most likely ilmenite. Vesicles occupy $3 \%-5 \%$ of total volume. They are present in two forms, round $(\sim 0.1 \mathrm{~mm})$ and elongate, and are irregular and locally interconnected. Most are unfilled, but a few are completely or partially filled by devitrified glass, and a few, especially near fracture surfaces, are filled by secondary green or orange smectite. They generally range in size up to $0.5 \mathrm{~mm}$ but in places are as large as $2 \mathrm{~mm}$. Where present, glass is $1-3 \mathrm{~mm}$ thick with $50 \%-100 \%$ palagonitization close to outer surfaces.

The one sample of pillow basalt (Sample 304U1311A-1R-1, 34-36 cm) analyzed for major and trace element geochemistry suggests that the basalt is a primitive tholeiite, with an $\mathrm{Mg \#}$ of 66 . The sample is characterized by loss on ignition values of $-0.05 \mathrm{wt} \%$ and $\mathrm{H}_{2} \mathrm{O}$ and $\mathrm{CO}_{2}$ below detection limit. It has $48.97 \mathrm{wt} \% \mathrm{SiO}_{2}, 9.63 \mathrm{wt} \% \mathrm{MgO}, 9.82 \mathrm{wt} \%$ $\mathrm{Fe}_{2} \mathrm{O}_{3}, 16.81$ wt $\% \mathrm{Al}_{2} \mathrm{O}_{3}, 12.61 \mathrm{wt} \% \mathrm{CaO}, 2.17 \mathrm{wt} \%$ $\mathrm{Na}_{2} \mathrm{O}, 0.04 \mathrm{wt} \% \mathrm{~K}_{2} \mathrm{O}$, and $1.12 \mathrm{wt} \% \mathrm{TiO}_{2}$. It has 8.8 ppm Ba, 83 ppm Sr, 26 ppm Y, 57 ppm Zr, and 38 ppm Sc, virtually equivalent to the basalt sampled in Hole U1310B. Basalt from both hanging wall sites reflect a depleted source.

\section{Operations summary}

\section{Hole U1311A}

After poor drilling conditions prevented our attempt at deep penetration at the primary site on the hanging wall, we selected an alternate site based on seismic and bathymetry data $1 \mathrm{nmi}$ west of Site U1310. This site was interpreted to be near the westernmost edge of the presumed hanging wall outcrop, where a single-bit hole might penetrate the detachment fault. A subsea camera survey revealed a smooth, sedimented surface with rare accumulations of angular to subrounded, submeter-sized boulders. The seabed at this location slopes to the south, and during our survey we crossed two small $(2-3 \mathrm{~m})$ east-facing scarps with rubble-strewn surfaces (Fig. F1). We traversed upslope (north), noting several outcrops of angular blocks interpreted to be probable talus, and at the end of the traverse encountered a steep southfacing cliff at least $20 \mathrm{~m}$ high. The subrounded morphology of outcrop at the base of the cliff suggested pillow basalt flows, so we traversed back to a location $\sim 70 \mathrm{~m}$ south of the cliff face to attempt coring in an area devoid of visible rubble.

Hole U1311A was initiated with a rotary core barrel (RCB) bottom hole-assembly (BHA) at $2040 \mathrm{~h}$ on 18 December 2004. Owing to the spacing of BHA components, our first coring interval was $12 \mathrm{~m}$. High and erratic torque was constant during the $25 \mathrm{~h}$ required to core this interval, and rock fallen into the hole had to be redrilled several times. Running the bit back to bottom after recovering Core 304-U1311A1R (Table T1), the driller determined that there was at least $3 \mathrm{~m}$ of fill in the $12 \mathrm{~m}$ hole. After several hours attempting to clear the hole proved unsuccessful, Hole U1311A was abandoned. With more than half the potential bit life expended during this first coring interval, we elected to recover the BHA and replace the bit before attempting another hole.

\section{Hole U1311B}

For our second coring attempt at Site U1311, we conducted another subsea camera survey starting 100 m northwest of Hole U1311A, above the cliff face observed during our first camera survey at this site. During our second survey, we saw a broad expanse of smooth sediment with rare rounded and sedimentcovered rocks. Given the poor drilling conditions we had encountered during all our attempts to drill on the hanging wall, we had little confidence that RCB coring from the seafloor would allow deep enough penetration to meet our objectives before bit life was exhausted. Our engineers suggested the alternative strategy of drilling a large-diameter hole without coring and then attempting a reentry into that hole with a conventional RCB BHA. We hoped that the large-diameter bit would be more efficient at clearing the rubble falling into the hole and we could begin coring with additional weight on bit to allow faster and deeper penetration. Because drilling with any rotary system was likely to encounter the same poor drilling conditions we suffered with the RCB, we decided to attempt to drill the large-diameter hole with a wing-style reaming hammer bit. Although we were not convinced the hammer system with a wing-style bit could set casing in this environment, we had seen it open a hole and felt this strategy had a higher chance of success than using a large-diameter rotary bit.

However, after $10 \mathrm{~m}$ of penetration, downward motion with the bit ceased while we attempted to hammer through rubble falling into the hole. After $19 \mathrm{~h}$, we were not able to advance the bit to the bottom of the hole, so the attempt was abandoned.

Publication: 3 June 2006

MS 304305-105 
Figure F1. Map of Site U1311 operations area developed from subsea camera survey observations. The survey for Hole U1311A began at $1546 \mathrm{~h}$ on 18 December, following the expanding box illustrated by the straight lines in the lower part of the figure (the actual path of the camera is not plotted, but tracking the camera via sonar indicated the camera followed the ship's path). Hole U1311A was initiated on the east side of our survey area, in a smooth sediment blanket with no obvious talus present. Hole U1311B was spudded $\sim 104 \mathrm{~m}$ north of Hole U1311A, in $36 \mathrm{~m}$ shallower water depth (above the cliff face seen during the survey for Hole U1311A). Camera depths are in meters below sea level (mbsl). mbrf $=$ meters below rig floor.

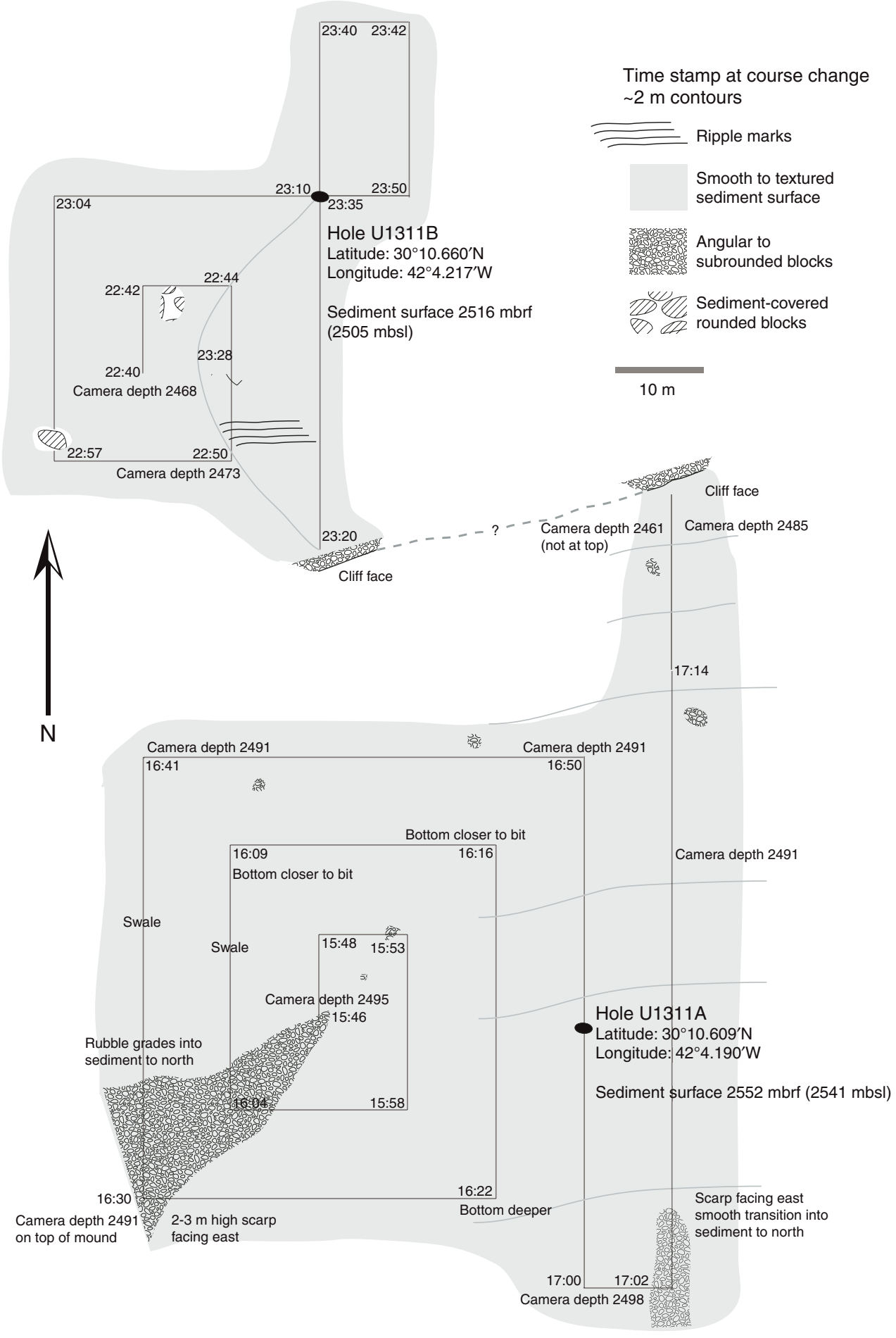


Table T1. Coring summary table, Site U1311.

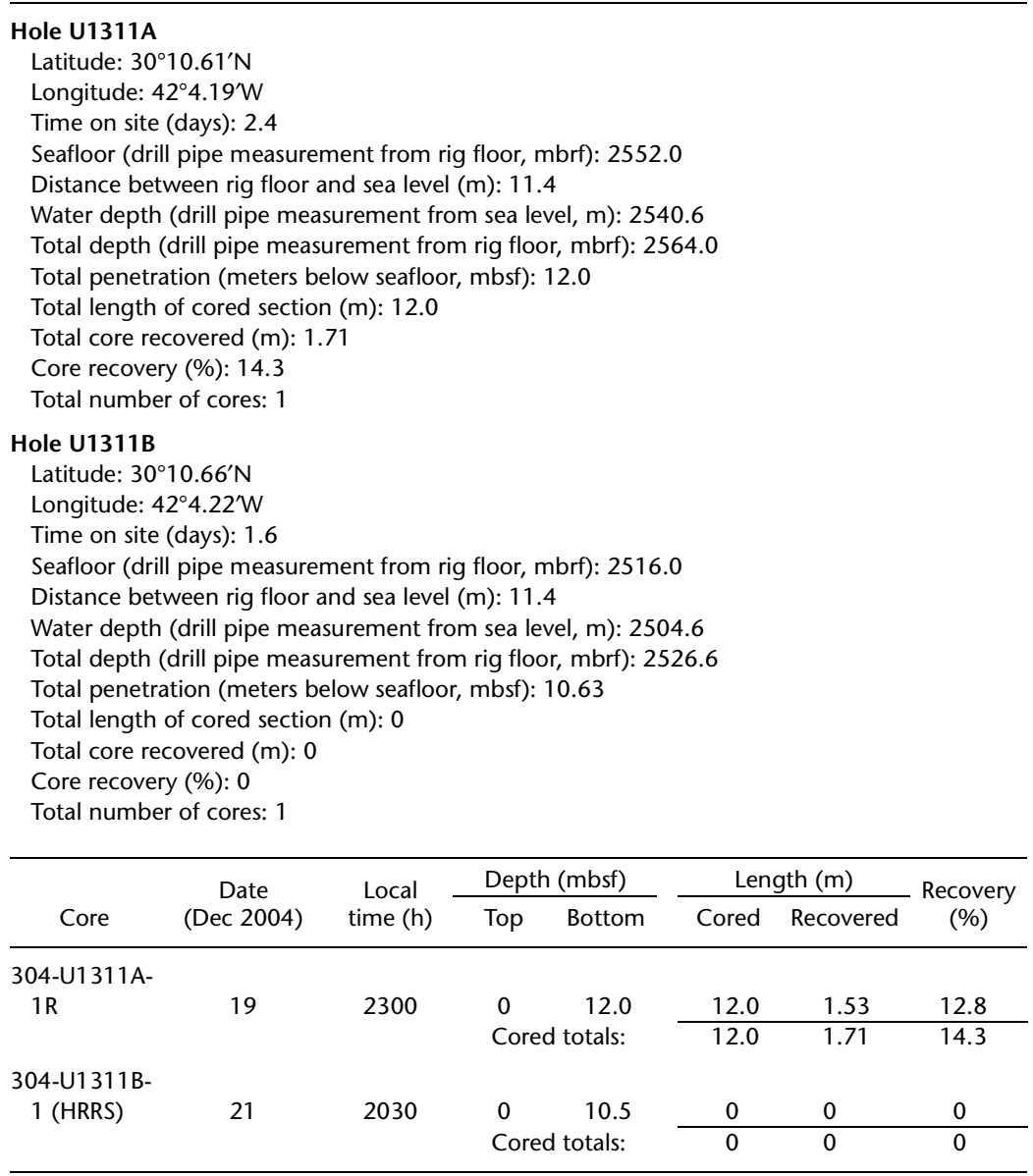

Note: HRRS = Hard Rock Reentry System. 